\title{
СИНТЕЗ И ПОИСК ФАРМАЦЕВТИЧЕСКИХ СУБСТАНЦИЙ НА ОСНОВЕ 2(3)-[2-(АДАМАНТАН-1-ИЛ)-2- ОКСОЭТИЛИДЕНГИДРАЗОНО]-5-(ГЕТ)АРИЛ-ФУРАН-3(2)-ОНОВ
}

\section{Н.А. Пулина, А.С. Кузнецов, А.И. Краснова, С.В. Чащина}

Федеральное государственное бюджетное образовательное учреждение высшего образования «Пермская государственная фармацевтическая академия» Министерства здравоохранения Российской Федерации, 614990, Пермь, ул. Полевая, д. 2

DOI: 10.19163/MedChemRussia2021-2021-498

E-mail:pulina-nata@mail.ru

На основе реакций Штаудингера и диза-Виттига,при взаимодействии 4-(гет) арил-2,4-диоксобутановых кислот, 5-(гет)арилфуран-2,3-дионов и 1-(адамантан1-ил)-2-(трифенилфосфоранилиденгидразоно)этанонов нами синтезированы 2(3)-[2-(адамантан-1-ил)-2-оксоэтилиденгидразоно]-5-(гет)арилфуран-3(2)-оны $(1,2)$. Сравнительное изучение химического поведения гидразонов 1, 2 с водой, алифатическими спиртами, производными алифатических тиолов, ароматическими аминами позволило синтезировать ряды соединений 3-6, 7-10.

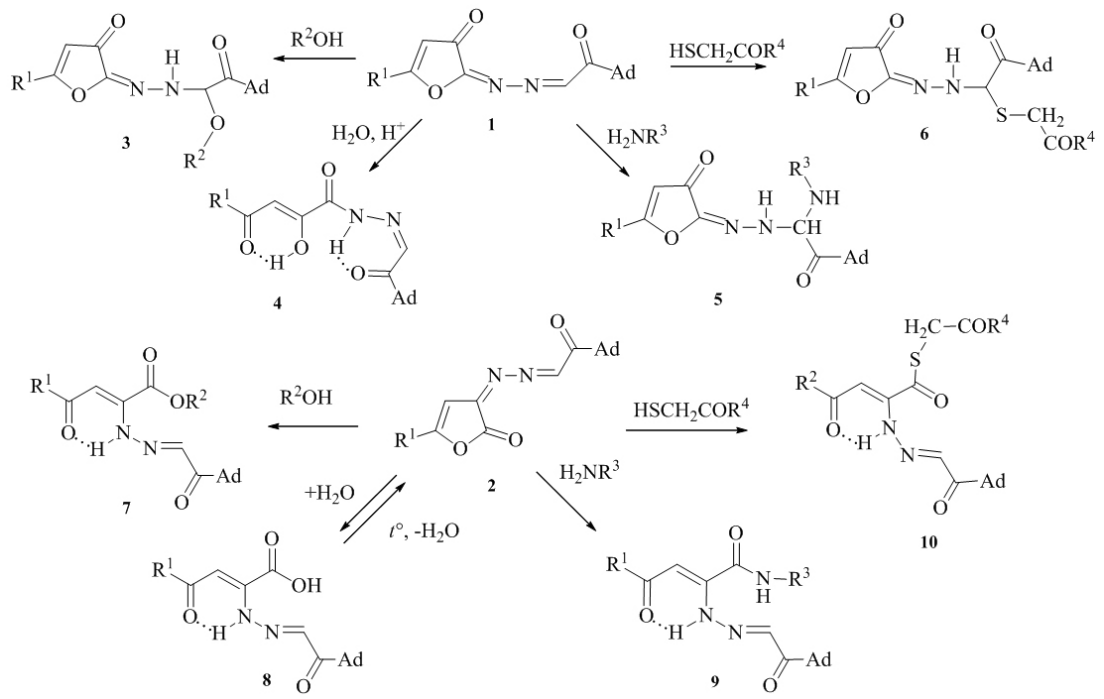

В результате фармакологического скрининга обнаружены вещества, обладающие высокой антифлавивирусной, противомикробной, гемостатической, анальгетической, противовоспалительной, фагоцитарной, анксиолитической активностью. Обсуждается связь строения с действием и возможный механизм биологической активности соединений 1-10. 